\title{
(Auto)percepcja tożsamości w ujęciu współczesnej młodzieży na podstawie Oblicza Szymona Kołody
}

\section{KEYWORDS}

young people's identity, Homo eligens, education, cyberspace, masculinity, patriotism

\begin{abstract}
Judzińska Aneta, (Auto)percepcja tożsamości w ujęciu współczesnej młodzieży na podstawie "Oblicza” Szymona Kołody [(Self)perception of young people's identity in "The Face" by Szymon Kołoda]. Kultura - Społeczeństwo - Edukacja nr 1(13) 2018, Poznań 2018, pp. 235-245, Adam Mickiewicz University Press. ISSN 2300-0422. DOI 10.14746/kse.2018.13.17.
\end{abstract}

The author, by taking into account popular and scientific discourse about "liquid", "globalized" identity (viewed in the context of various social and family roles), attempts to reconstruct an image of a contemporary teenager's identity, referring to "The Face", a 2-minute impression by seventeen year old Szymon Kołoda. On this basis she shows areas of participation of contemporary young people, who balance between two realities: the real and the virtual one. The author supports her reasoning with the concept of hybrid identity by Zygmunt Bauman and the global teenager / culture of diffusion by Zbyszko Melosik. The aim of this article is to make a subjective, socio-psychological interpretation of identity creations present in Szymon Kołoda's picture, rather than psychological diagnosis of the teenage actor's "inner integrity".

Film Oblicze siedemnastoletniego Szymona Kołody, ucznia IV LO w Żarach, zwyciężył w konkursie kampanii „Oglądam, czuję, myślę - młodzi w kinie” zorganizowanym przez Nowe Horyzonty Edukacji Filmowej oraz Polski Instytut Sztuki Filmowej. W tej dwuminutowej impresji zostały przedstawione różnorodne role/ aktywności społeczne „doświadczane” i „odgrywane” przez młodego reżysera. 
Idąc o krok dalej, można przyjąć, że stanowią reprezentację niejednorodnego obrazu tożsamościowego współczesnego nastolatka. Wśród licznych „kreacji” dostrzegamy kolejno: nagi tors młodego mężczyzny, sylwetkę ucznia, fana zespołu rockowego, gracza komputerowego, biznesmena, żołnierza, nastolatka prowadzącego rozmowę telefoniczną, mężczyznę golącego zarost oraz kibica sportowego. Oblicze pokonało ponad 40 produkcji nadesłanych na konkurs. Jak podkreśla Szymon: „Od dawna zastanawiam się, kim jestem, dokąd zmierzam. Postanowiłem pokazać swoje różne wcielenia, nakładając przenikające się kadry. Mimo że do dyspozycji miałem tylko zwykły aparat fotograficzny, udało się osiągnąć zamierzony efekt” (Wygrało „Oblicze”, 2013).

W dobie „płynnej tożsamości” (Bauman, 2007b: 18) coraz trudniejszym zadaniem - również na gruncie założeń psychologii rozwojowej - jest zdefiniowanie specyfiki „tożsamościowej karuzeli”, na której „wiruje” współczesny nastolatek. Przemiany społeczne i kulturowe, w tym procesy globalizacji, redefiniują tradycyjne spojrzenie na kwestie spójnego i świadomego poczucia siebie w świecie (zarówno wewnętrznym, jak i zewnętrznym) (Paleczny, 2008: 133-134). Dający się zaobserwować współcześnie „stan nieciągłości kulturowej” prowadzi do „relatywizacji jednostkowych tożsamości społecznych”, które stają się niewrażliwe (przynajmniej z założenia) na płeć, klasę społeczną czy etniczność (Ogrodzka-Mazur, 2015: 108).

Czym zatem jest tytułowe Oblicze, a raczej Oblicza, Szymona Kołody? Czy możemy je rozpatrywać w kontekście dojrzałych „kreacji” wynikających ze świadomego podjęcia zobowiązania poprzedzonego intensywną eksploracją (tożsamość osiągnięta)? A może są to wzbogacone aktywnym poszukiwaniem zmienne koncepcje siebie, zmierzające dopiero do odkrycia prawdy o sobie (tożsamość moratoryjna)? Istnieje jeszcze inna droga: być może są to po prostu pozbawione elementu eksploracji, tymczasowe (bo w konsekwencji jawiące się jako frustrujące) zobowiązania wynikające z fascynacji osobami znaczącymi (tożsamość lustrzana)? (Bardziejewska, 2013: 367-370). Celem niniejszego tekstu nie jest próba udzielenia odpowiedzi na powyższe pytania w celu stworzenia psychologicznej diagnozy poziomu wewnętrznej spójności, lecz raczej pragnienie dokonania, zabarwionej subiektywizmem, socjologicznej i psychologicznej interpretacji prezentowanych przez autora tożsamościowych „kreacji”.

Mając świadomość złożoności i konceptualizacyjnej niejednoznaczności w definiowaniu pojęcia tożsamości, które można rozpatrywać chociażby w wymiarze substytucjonalnym, psychicznym czy społecznym i kulturowym, swoje rozważania będę prowadziła w „duchu syntezy” wyżej wymienionych kategorii, zwracając szczególną uwagę na ich trzeci - społeczny i kulturowy aspekt (Paleczny, 2008: 20-23). Jest on postrzegany jako „kluczowy determinant subiektywnego wymia- 
ru rzeczywistości (...) [który; przyp. A.J.] pozostaje w dialektycznym związku ze światem społecznym" (Cybal-Michalska, 2006: 89). Przywołam w tym miejscu definicję tożsamości kulturowej autorstwa Evy Zamojskiej. Badaczka nadaje jednostce podmiotową sprawczość w procesie (auto)identyfikacji. Zdaniem naukowczyni tożsamość kulturowa jest to „względnie trwały konstrukt świadomości jednostki, powstający w wyniku jej subiektywnych wyborów, który zwykle bywa zwany autokoncepcją jednostki. Jej treść czerpana jest z zewnętrz, w tym wypadku z takich czy innych systemów kultury" (Zamojska, 1998: 23).

Weryfikując prezentowane w filmie tożsamościowe sylwetki, uwagę zwróciłam szczególnie na jedną, epatującą nagością bohatera. Autor bezpośrednio eksponuje ją na początku i końcu impresji. Według mnie, jej wyjątkowość tkwi w specyfice samej „kreacji”, w której dostrzegam oksymoroniczność odzwierciedloną w postaci „ubranej nagości”. Ów ubiór postrzegam raczej w kontekście symbolicznym aniżeli dosłownym. Przyjmuje on formę zdobiącej ciało (ściślej: okolice twarzy i uszu) biżuterii (piercingu, który notabene towarzyszy każdej z zaprezentowanych kreacji) mającej prawdopodobnie na celu nadanie ostrzejszego (zindywidualizowanego) kolorytu bezbarwnej (niewyróżniającej się) nagości. W dalszej perspektywie można założyć, iż ów „proceder” stanowi analogię wobec samego procesu kształtowania się tożsamości, to jest dążenia do „poszukiwania siebie” (Krauze-Sikorka, Klichowski, 2013: 10), jak również odkrycia własnej „wyjątkowości, indywidualności i odrębności” (Cybal-Michalska, 2012: 60). Niniejsza „kreacja” jawi się jako zindywidualizowany fragment tej „tożsamościowej opowieści”. Wydaje się jednak, że to nie jedyny kontekst, który możemy dostrzec, interpretując jej znaczenie. W prowadzonej analizie warto uwzględnić również perspektywę „funkcji tła”, którą spełnia owa sylwetka. Można wysunąć przypuszczenie, iż „ubrana nagość” bohatera, filtrująca każdą z dryfujących tożsamości, stanowi odzwierciedlenie tożsamościowego rdzenia ${ }^{1}$, metaforę względnej stałości, o którym wspomina zarówno Zbyszko Melosik, jak i Anthony Giddens (Giddens, 2001: 113). Z kolei Zygmunt Bauman określa go mianem jądra tożsamościowego, którym jest homo eligens (człowiek wybierający) (Bauman, 2007: 54-55).

Zatem Baumanowski homo eligens odważnie sięga po kuszące formą i treścią wytwory kultury, podejmując zróżnicowane role społeczne: ucznia, uśmiechniętego fana zespołu rockowego, gracza komputerowego, władczego biznesmena, żołnierza-patrioty, nastolatka prowadzącego rozmowę telefoniczną, mężczyznę

${ }^{1}$ Który traci już wprawdzie „dawną jednoznaczność, stabilność (...) [jednak; przyp. A.J.] nawet resetowanie części rdzenia tożsamości nie oznacza już pozbycia się cząstki własnego 'ja’, ponieważ owo 'ja' jest w nieustannym bezruchu” (Melosik, 2013: 157). 
golącego zarost czy sportowca-kibica. Jednocześnie możemy dostrzec, że każdej z performatywnych tożsamości towarzyszą określone stany emocjonalne i zachowania: złość, radość, poczucie dumy, skupienie, zaangażowanie, niezadowolenie, charakterystyczne dla okresu adolescencji. To w niej przeplatają się dwie (a nawet trzy!) czasoprzestrzenie ${ }^{2}$, stanowiące obszar dla fundamentalnych pytań: Kim byłam/byłem? Kim jestem? Kim będę? Szczególnie ekspresyjna - zapewne z samej swojej definicji - wydaje się sylwetka wyrażająca złość bądź furię, którą oddaje tożsamość sportowca-kibica. Prawdopodobnie stanowi nie tylko płaszczyznę realizacji piłkarskich pasji czy pragnień identyfikacji z ulubionym klubem sportowym. W pośredni sposób staje się też „wentylem emocjonalnym”, dającym upust kłębiącym się w ciele nastolatka negatywnym emocjom.

Analiza poszczególnych „sylwetek tożsamościowych” potwierdza ich hybrydyczny (nieokreślony i wyizolowany, za: Bauman) charakter. Z kolei wielopłaszczyznowe współistnienie, zakorzenione w permanentnej różnorodności, oddaje specyfikę kultury rozproszenia (por. Melosik, 2014). Potwierdzenie powyższego założenia stanowi druga oraz trzecia „tożsamościowa kreacja”. W moim przekonaniu odzwierciedla stosunek bohatera impresji do pracy (tutaj nauki) i czasu wolnego. Ujawniają się tu dwa opozycyjne obrazy. Pierwszy, przedstawiający beznamiętnie spoglądającego w obiektyw kamery młodzieńca, którego zarówno wyrażający niezadowolenie wyraz twarzy (a może nawet i bunt), jak i strój (koszula jeansowa oraz t-shirt) mogą świadczyć o przebywaniu na terenie szkoły, oraz drugi, będący sportretowanym antonimem pierwszego. W tym przypadku oczom odbiorcy ukazuje się uśmiechnięta, pełna pozytywnych emocji twarz adolescenta, ubranego w sportową bluzę z napisem METALICA ${ }^{3}$.Zatem pierwsza tożsamościowa sylwetka prawdopodobnie oddaje rzeczywistą (bądź powszechnie uznawaną za chroniczną) „napiętą” relację na linii nastolatek - szkoła, o której w tekście Młodzież a przemiany kultury wspótczesnej nadmienia Zbyszko Melosik. Badacz podkreśla, że młody człowiek „szkoły nie lubi, lecz dba o to, «aby nie mieć kłopotów»” (Melosik, 2005: 24). Wyeksponowany w niniejszej „kreacji” wątek edukacji skłania mnie do wyprowadzenia wniosku, że formalna nauka przyjmuje w tym ujęciu ambiwalentne znaczenie. Pod względem emocjonalnym budzi niechęć i dezaprobatę. Poznawczo zaś staje się dla młodzieży „instrumentalnie istotnym”, (lecz nie jedynym - szczególnie w polskiej rzeczywistości) kanałem ruchliwości społecznej (Gromkowska-Melosik, 2008: 12) oraz aprobowanym społecznie (w ujęciu Mer-

\footnotetext{
${ }^{2}$ Mam tutaj na myśli przeszłość, teraźniejszość i przyszłość.

${ }^{3}$ Być może symbolizująca partycypację Szymona w interesującym wydarzeniu muzycznym $\mathrm{np}$. koncercie ulubionego zespołu.
} 
tonowskim) środkiem do realizacji podyktowanych kulturą konsumpcjonizmu celów (Pospiszyl, 2008: 30). Przeciwną konotację wzbudza natomiast „kreacja” druga. Odczytuję ją jako pożądaną w oczach nastoletnich odbiorców, bowiem „muzyka odgrywa bardzo ważną rolę w [ich; przyp. A.J.] życiu, dostarczając [im; przyp. A.J.] przyjemności i fascynacji” (Melosik, 2013: 141). Stanowi jeden z kluczowych elementów tworzących kulturę młodzieżową. Jest nośnikiem wartości (jak również doskonałą przestrzenią do negacji wartości nieaprobowanych) aprobowanych przez adolescentów. Jej generacyjny charakter odzwierciedlają słowa Rebecci A Goldstein, która wskazuje, że „Każde pokolenie wydaje się mieć własną ekspresję muzyczną; słuchanie najnowszej muzyki może pomóc dorosłym w znalezieniu istniejących podobieństw i różnic" [w porównaniu z muzyką pochodzącą z okresu ich młodości; przyp. A.J.] (Goldstein, 2006: 10).

W Obliczu widoczna staje się również ekspresja wirtualnej przestrzeni, po której swobodnie porusza się współczesny nastolatek. Bohater filmowej impresji potwierdza swoją kolejną „kreacją” naukowy dyskurs na temat cyberprzestrzeni jako kolejnej płaszczyzny socjalizacji i kształtowania tożsamości współczesnych adolescentów (w obrazie filmowym pojawiają się następujące gadżety: słuchawki komputerowe z mikrofonem oraz telefon komórkowy). Wirtualna przestrzeń jawi się tutaj jako niezwykle atrakcyjna, a zarazem istotna sfera życia, w której (w większości) partycypują młodzi odbiorcy. Przejawy owej atrakcyjności tkwią w specyficznych możliwościach, jakie niesie ze sobą obietnica realizacji niedokonanych w rzeczywistości pragnień, bowiem „w Internecie możliwe jest wykreowanie własnej tożsamości” (Krauze-Sikorka, Klichowski, 2013: 181). Wzmożona w okresie adolescencji potrzeba rówieśniczej akceptacji stanowi jeden z podstawowych impulsów skłaniających nastolatka do „ubarwienia” swojej osobowości i/lub cielesności. Płaszczyznę do realizacji owych dążeń, stanowią w tym przypadku portale społecznościowe, których - zdaniem Emilii Wołyniec - wykorzystanie „do kreowania własnego wizerunku staje się obecnie normą" (Wołyniec, 2014: 90). Tym samym konotacja terminu „realny” rozmywa się w oceanie wirtualnych paradoksów, kreśląc wysoce eklektyczną mozaikę współistnienia - czy raczej mentalnego rozszczepienia - pomiędzy dwoma światami: rzeczywistym i wirtualnym. Nie dziwi więc, że globalny nastolatek w rozumieniu Zbyszko Melosika „z największą swobodą przemieszcza się po wirtualnej internetowej przestrzeni (...). Ma nawyk nieustającej telefonicznej (komórkowej) i SMS-owej komunikacji z przyjaciółmi i znajomymi” (Melosik, 2013: 141). Jednocześnie cały ten „kulturowy spektakl” odgrywa $\mathrm{w}$ atmosferze swobodnego i niekontrolowanego przepływu informacji, ponieważ „wiedza stała się eksterytorialna” (Jakubowski, 2011: 24). Dokonując próby konceptualizacji „wirtualnego fenomenu”, odwołam się do zjawiska tak zwanej „tożsa- 
mości sieciowej”. Justyna Lipińska definiuje ją jako „ogół zdolności prezentowania siebie w Internecie, umiejętność manipulowania swoją tożsamością, a przy okazji nieograniczona możliwość manipulowania innymi użytkownikami sieci” (Lipińska, 2008: 212). Mamy więc tutaj do czynienia z wachlarzem „cyberinter(intra) personalnych” kompetencji, kształtujących poziom jakości wirtualnych relacji.

W obrazie tożsamościowym Szymona Kołody pojawia się również aspekt płciowości - cielesności, o czym świadczy przedostatnia sylwetka młodego reżysera. Odzwierciedla tak w wymiarze biologicznym, jak i społecznym oraz kulturowym obraz młodego mężczyzny, uwikłanego w kulturowe praktyki pielęgnowania męskości (golącego zarost). Warto podkreślić, że owa męskość nie ma już tak homogenicznego charakteru, jak miało to miejsce chociażby w okresie poprzedzającym polską transformację ustrojową. Obecny w kulturze współczesnej kryzys męskości (Melosik, 2006) spowodował narodziny nowych "globalnych trendów w rekcjach na brak uniwersalnych kryteriów męskości” (Doroba-Sawa, 2008: 61). W przekonaniu Marty Doroby-Sawy, odwołującej się do poglądów wielu (zarówno rodzimych, jak i zagranicznych) badaczy i badaczek kultury współczesnej, istnieją dwie elementarne ścieżki ewoluowania męskości: hipermaskulinizacja, jako wynik zniekształconej reakcji tradycyjnej męskości „zniesmaczonej” feminizacją wielu obszarów życia, oraz feminizacja ciała i sublimacja osobowości, która „zastępuje stereotypową męskość tradycyjną kobiecością" (Doroba-Sawa, 2008: 62). Dokonując próby umiejscowienia „kreacji” Kołody w powyższym dyskursie, zaryzykuję przypuszczenie wyprowadzone na postawie koloru (czerwony) i kroju koszulki (bez rękawów), iż przejawia on raczej skłonność kroczenia pierwszą ścieżką (hipermaskulinizacji). Swoją interpretację konstruuję na podstawie popkulturowego systemu znaczeń owych atrybutów („agresywnej czerwieni” i wyeksponowanych ramion), postrzeganych jako wyraz tęsknoty za tradycyjną, atawistyczną (?) męskością. Jej odzwierciedlenie stanowią amerykańskie „filmy akcji” kreujące wizerunek „super męskich” bohaterów epatujących tężyzną fizyczną (np. Rocky). W przypadku kreacji Kołody nie można jednoznaczne stwierdzić, z jakim poziomem natężenia/zaangażowania owa hipermaskulinizacja (o ile w ogóle ma miejsce) będzie zachodziła i jakie inne wzorce męskości również zostaną uaktywnione. $\mathrm{W}$ analizie należy bowiem uwzględnić jeszcze jeden aspekt, o którym wspomina Krzysztof Arcimowicz. Zauważa on, że „współczesny mężczyzna jest osaczony przez dużą liczbę dyskursów proponujących różne, nawet przeciwstawne wzory męskości” (Arcimowicz, 1998: 51). Za przejaw adaptacji możemy zatem przyjąć fenomen wystąpienia zróżnicowanych kombinacji i połączeń fragmentarycznych tożsamości, prowadzących w konsekwencji do powstania męskiej „mozaiki tożsamościowej”, po której z większą lub mniejszą gracją „dryfują” młodzi mężczyźni. 
W tym kontekście kluczowa wydaje się koncepcja męskości autorstwa Raewyn Connell. Badaczka odrzuca w niej tradycyjne założenie o istnieniu monolitycznego modelu męskości. Zwraca uwagę na złożoność i zmienność elementów kreujących jego znaczenie. Formułuje założenie o „wielości konstruktów męskości” zależnych od kontekstu czasu, miejsca, społeczności oraz kultury. Można więc mówić tu o trzech rodzajach męskości: hegemonicznej, współuczestniczącej i podporządkowanej (Wojnicka, Ciaputa, 2011: 12-13). Pierwsza odwołuje się do „kulturowo dominującego ideału męskości, skoncentrowanego na autorytecie, fizycznej tężyźnie i sile, heteroseksualności i płatnej pracy”. Istotną rolę odgrywa tu dążenie do władzy i dominacji. Z kolei męskość współuczestnicząca stanowi odpowiedź na niezrealizowane w pełni aspiracje tych mężczyzn, którzy pragną znaleźć się w pierwszej grupie, lecz nie są w stanie w pełni „doścignąć ideału”. Ostatni model charakteryzuje mężczyzn, którym nie udało się sprostać standardom zarówno pierwszej, jak i drugiej grupy. Uwarunkowane jest to zazwyczaj pochodzeniem etnicznym i/lub orientacją seksualną (Wojnicka, Ciaputa, 2011: 12-13).

Wyobrażenia dotyczące wzorów i schematów wpisujących się w pojęcie płci są czytelne również w piątej „kreacji” Kołody. Nastoletni reżyser prezentuje w niej kolejne wcielenie męskości, będące - w przeciwieństwie do poprzedniego, skoncentrowanego na „tu i teraz” - „snem o przyszłości”. Można przyjąć, że stanowi ucieleśnienie chłopięcych marzeń na temat osiągnięcia Connellowskiej hegemonicznej męskości. Szymon przyjmuje tutaj postać dojrzałego (pod względem zawodowym) mężczyzny, który zarówno poprzez mimikę, postawę, jak i ubiór wyraża przynależność do wysokiego statusu społecznego. Biznesowy image (ciemny garnitur i biała koszula), wzbogacony nutą nonszalancji (brak krawatu, palenie cygara), kreuje obraz człowieka, przed którym międzynarodowe rynki finansowe wydają się nie mieć tajemnic. Można odnieść wrażenie, że ów mężczyzna, stereotypowo kojarzony z symbolem wysokiego statusu, władzy i bogactwa, prawdopodobnie stanowi tu ucieleśnioną wizję „wielkich nadziei i wielkich marzeń" (Arnett, 2015: 1) współczesnego adolescenta o pełnej i „obfitej” partycypacji w społeczeństwie konsumpcji. Odzwierciedlenie tych pragnień potwierdza „fenomen kultu pieniądza” (Pasierbek, Fearn, Ziebertz, 2005: 87) oraz „kultu sukcesu”. Taka optyka wpisuje się w treść współczesnych przekazów kulturowych kreowanych przez mass media. Punkt wyjścia stanowi w tym kontekście pojęcie pracy zawodowej, ściślej kariery, w klasycznym rozumieniu odzwierciedlającej „dążenie do władzy, stanowiska (pozycji) i pieniędzy" (Melosik, 2005: 26). Wniosków na temat jej znaczenia dostarczają badania Agnieszki Cybal-Michalskiej zaprezentowane w monografii Młodzież akademicka i kariera zawodowa. Ujawniają one, iż kariera coraz częściej stanowi dla młodych ludzi synonim uznania, autorytetu, poczucia 
bezpieczeństwa oraz szansy na zdobycie doświadczenia (Cybal-Michalska, 2013: 303-304). Ponadto, jednym z podstawowych wskaźników jej ujmowania staje się kryterium awansu, postrzegane przez pryzmat osiągania stałych i szybkich nagród zawodowych (Cybal-Michalska, 2013: 310). Dodatkowych kontekstów dostarcza stosunek badanych wobec terytorialności. Podobnie jak dzieje się to w przypadku multiglobalnego przepływu informacji, terytorialność wydaje się nie stanowić dla młodych ludzi problemu. Starza tym samym „świat bezgranicznych karier” (Cybal-Michalska, 2013: 352). Owa pragmatyczność wpisuje się w obraz globalnego nastolatka, który, jak podkreśla Zbyszko Melosik, choć „za nauką nie przepada, to rozumie, że wykształcenie i certyfikaty są wstępnym warunkiem zawodowego sukcesu i mogą się przydać w przyszłości” (Melosik, 2013: 141).

W dwuminutowej impresji zostaje też poruszona kwestia poczucia tożsamości narodowej i patriotyzmu. Świadczy o tym zaprezentowany odbiorcom obraz polskiego żołnierza, trzymającego prawą dłoń na sercu. Tak wykreowana wizja młodego miłośnika ojczyzny pozostaje w pewnej opozycji względem tradycyjnej koncepcji współczesnego nastolatka, którego tożsamość „jest w znacznie mniejszym (lub nawet niewielkim) stopniu kształtowana przez wartości narodowe i państwowe, w znacznie większym - przez kulturę popularną, mass media oraz konsumpcję" (Melosik, 2013: 141), a świat stanowi pozbawioną granic globalną wioskę (Melosik, 1995: 93). Podejmując próbę wyjaśnienia powstającego tu dysonansu, odwołam się do wypowiedzi Krystyny Szafraniec, autorki raportu „Młodzi 2011”. W rozmowie z Tomaszem Słomczyńskim podkreśla, że

młodzi Polacy są romantyczni i pragmatyczni zarazem. Wbrew pozorom, są bardzo wrażliwi na punkcie historii własnego narodu. Najlepiej widać to za granicą, gdy w sytuacjach czysto towarzyskich dochodzi często do konfrontacji z reprezentantami innych narodowości - Anglikami, Niemcami, Francuzami czy Holendrami. Okazuje się wtedy, że ci młodzi, niby obojętni na własną historię Polacy potrafią być dumni z powstań, z tego, że ich przodkowie zawsze byli wszędzie tam, gdzie walczono o wolność. Honor, bohaterstwo, odwaga choć nieobecne w codziennym słowniku ludzi młodych - są czymś, co staje się "przebitką" w dyskusjach o cnotach narodów. (Szafraniec, 2013)

Powstaje w tym miejscu następujące pytanie: co zatem warunkuje współwystępowanie owego młodzieńczego romantyzmu i pragmatyzmu? Poszukując odpowiedzi na ten złożony problem, odwołam się do koncepcji tożsamości kontekstualnej. Z racji swojej relatywności ujmowana jest w kategoriach przeobrażającej się wizji siebie wytwarzanej w wyniku partycypacji jednostki w różnorodnych makrostrukturach (Nikitorowicz, 2015: 21). Zgodnie z poglądami Nicolai Hartmann zmianie ulega bowiem sposób odczuwania wartości, co powoduje „przesuwanie się 
horyzontu aksjologicznego". Oznacza to, że zasymilowana wartość (np. narodowa) wraz z upływem czasu traci swoją atrakcyjność. Tym samym wzmaga w jednostce potrzebę poszukiwania nowej. Nie oznacza to jednak, iż zostaje usunięta z ludzkiej świadomości: o ile „człowiek uchwycił już kiedyś pewną wartość” i jest ona dla niego nadal istotna, o tyle „nie może już [o niej; przyp. A.J.] zapomnieć” (Ogrodzka-Mazur, 2015: 112).

Podsumowując swoje rozważania, przywołam metaforę kulturowego surfin$\mathrm{gu}^{4}$, która w moim przekonaniu oddaje specyfikę tożsamości współczesnego nastolatka (i nie tylko nastolatka) dryfującego na falach popkulturowego oceanu. Wielobarwny repertuar propozycji i możliwości pozwala - przynajmniej na chwilę - czuć się częścią (jakiejś) całości, lecz uniemożliwia (bądź znacznie utrudnia) utrzymanie ponadczasowej spójności w zakresie dookreślania własnego Ja (w odniesieniu do tradycyjnego sposobu definiowania pojęcia tożsamości). Jedność jawi się tutaj raczej jako heterogeniczny konstrukt przyjmujący postać mozaiki różnorodnych światów społecznych nieustannie "przyjmowanych” i „wymienianych na nowe” w katalogu życiowych doświadczeń. Zdaniem Anthony’ego Giddensa, „tożsamościowe rozszczepienie" powoduje, że ,jednostka jest zmuszona sama tworzyć i przebudowywać swoją tożsamość ze względu na zmienne doświadczenia życia codziennego i skłonność nowoczesnych instytucji do fragmentaryzacji tożsamości jednostki" (Giddens, 2006: 254). Parafrazując słowa badacza, wysunę następujące przypuszczenie: konieczność permanentnego „przebudowywania” tożsamości przyjmuje formę niespecyficznej, poniekąd społecznie wymuszonej adaptacji wobec wysoce niejednorodnych i kulturowo niedookreślonych warunków, w których przyszło funkcjonować współczesnemu nastolatkowi. Dodatkowo, pojawia się jeszcze problem utrzymania „poczucia własnej wyjątkowości (Wood, Green-Wood, 1999: 327) i oryginalności. Jak podkreśla Zygmunt Bauman, „każda postulowana i/lub poszukiwana tożsamość (tożsamość jako problem i jako zadanie) jest uwikłana w podwójną zależność, z której nie sposób się wyzwolić. Żegluje ona między skrajnościami bezkompromisowej indywidualności i całkowitej przynależności” (Bauman, 2007a: 50-51). Balansowanie na granicy Eriksonowskiej intymności vs izolacji (Erikson, 2004: 90) odzwierciedla Baumanowska koncepcja jednostki. Zgodnie z jej założeniem, człowiek podejmuje różnorodne praktyki kształtowania własnej indywidualności i niepowtarzalności, a jednocześnie popada w marazm powszechności. Oznacza to, że mniej lub bardziej świadomie odtwarza narzucane

${ }^{4}$ Którą w swoich pracach posługiwał się zarówno Zygmunt Bauman (44 listy ze świata płynnej nowoczesności), Ryszard Kapuściński (Lapidaria), jak i Mark Stranger (Surfing Life). 
przez kulturę konsumpcji „ekskluzywne trendy", prowadząc w konsekwencji do społecznej uniformizacji indywidualizmu. Zatem, zdaniem Baumana, „paradoks polega na tym, że «indywidualność» jest «odruchem stadnym» i nakazem tłumu. Być jednostką oznacza nie różnić się od tłumu, być takim samym jak wszyscy" (Bauman, 2007a: 28). Doświadczanie owej sprzeczności może w konsekwencji doprowadzić do sytuacji, w której nieustannie wybierający, czy też - posługując się nomenklaturą psychologiczną w ujęciu Jamesa Marcii - eksplorujący zewnętrzne oraz wewnętrzne światy podmiot (nastolatek) nie tyle poszukuje, co przeszukuje kolejne płaszczyzny identyfikacji, odraczając moment podjęcia konkretnego zobowiązania (niekiedy przez całe życie).

\section{Literatura}

Arcimowicz K. (1998). Dwa paradygmaty męskości w kulturze męskiej. „Kwartalnik Pedagogiczny” nr 1/2, s. 51.

Arnett J.J. (2015). Emerging Adulthood: The Winding Road from the Late Teens Through the Twenties. Oxford.

Bardziejewska M. (2013). Okres dorastania. Jak rozpoznać potencjał nastolatków. [W:] A.I. Brzezińska (red.). Psychologiczne portrety człowieka. Praktyczna psychologia rozwojowa. Sopot, s. 367-370.

Bauman Z. (2007a). Płynne życie. Kraków.

Bauman Z. (2007b). Tożsamość. Rozmowy z Benedetto Vecchim. Gdańsk.

Cybal-Michalska A. (2006). Tożsamość młodzieży w perspektywie globalnego świata. Studium socjopedagogiczne. Poznań.

Cybal-Michalska A. (2012). Tożsamość w ponowoczesności - przyczynek do refleksji na temat społecznej konstrukcji obrazu ciała. [W:] Z. Lew-Starowicz, K. Waszyńska (red.). Przemiany seksualności w społeczeństwie współczesnym. Teoria i rzeczywistość. Poznań, s. 60.

Cybal-Michalska A. (2013). Młodzież akademicka a kariera zawodowa. Kraków.

Doroba-Sawa M. (2008). W labiryncie męskiej tożsamości: hipermaskulinizacja versus feminizacja ciała i sublimacja osobowości. „Przegląd Pedagogiczny” nr 2, s. 61.

Erikson E. (2004). Tożsamość a cykl życia, przeł. M. Żywicki. Poznań.

Giddens A. (2001). Nowoczesność i tożsamość. „Ja” i społeczeństwo w epoce późnej nowoczesności, przeł. A. Szulżycka. Warszawa.

Giddens A. (2006). Nowoczesność i tożsamość. „Ja” i społeczeństwo w epoce późnej nowoczesności, przeł. A. Szulżycka. Warszawa.

Goldstein R.A. (2006). Oh Puhleeze! Learning Youth Culture. [W:] S.R. Steinberg, P. Parmar, B. Richard (eds). Contemporary Youth Culture: An International Encyclopedia, Vol 1. Westport, s. 10.

Gromkowska-Melosik A. (2008). Stratyfikacja, ruchliwość społeczna i edukacja. [W:] A. Gromkowska-Melosik, T. Gmerek (red.). Problemy nierówności społecznej w teorii i praktyce edukacyjnej. Kraków, s. 12.

5 Tworzące iluzję ograniczonego dostępu, tak, jak gdyby były zarezerwowane wyłącznie dla nielicznych. 
Jakubowski W. (2011). Media, tożsamość i edukacja. [W:] W. Jakubowski, S. Jaskulska (red.). Kultura mediów, ciało i tożsamość: Konteksty socjalizacyjne i edukacyjne. Kraków, s. 24.

Krauze-Sikorka H., Klichowski M. (2013). Świat Digital Natives. Młodzież w poszukiwaniu siebie i innych. Poznań.

Lipińska J. (2008). Tożsamość sieciowa. [W:] M. Wawrzak-Chodaczek (red.). Komunikacja społeczna $w$ świecie wirtualnym. Toruń, s. 212.

Melosik Z. (1995). Postmodernistyczne kontrowersje wokół edukacji. Poznań-Toruń.

Melosik Z. (2005). Młodzież a przemiany kultury współczesnej. [W:] R. Leppert, Z. Melosik, B. Wojtasik, Młodzież wobec (nie)gościnnej przyszłości. Wrocław, s. 24.

Melosik Z. (2006). Kryzys męskości w kulturze współczesnej. Kraków.

Melosik Z. (2013). Kultura popularna i tożsamość młodzieży. W niewoli władzy i wolności. Kraków.

Melosik Z. (2014). Pedagogika i konstrukcje tożsamości młodzieży $w$ „kulturze kontroli” $i$ „kulturze rozproszenia”. „Studia Edukacyjne” nr 31.

Nikitorowicz, J. (2015). Dylematy patriotyzmu, nacjonalizmu i ustawicznie kształtującej się tożsamości. Wprowadzenie do książki. [W:] J. Nikitorowicz (red.). Patriotyzm i nacjonalizm. Ku jakiej tożsamości kulturowej? Kraków, s. 21.

Ogrodzka-Mazur E. (2015). (Nie)obecność patriotyzmu w świadomości aksjologicznej młodego pokolenia Polaków. „Przesuwanie się horyzontu aksjologicznego” czy kryzys w wartościowaniu?. [W:] J. Nikitorowicz (red.). Patriotyzm i nacjonalizm. Ku jakiej tożsamości kulturowej? Kraków, s. 108.

Paleczny T. (2008). Socjologia tożsamości. Kraków.

Pasierbek W., Fearn M., Ziebertz H.G. (2005). Poland: family and fith. [W:] H.G. Ziebertz, W.K. Kay (red.). Youth in Europe: An International Empirical Study about Life Perspectives. Münster/ Hamburg/London, s. 87.

Pospiszyl I. (2008). Patologie społeczne. Warszawa.

Szafraniec K. (2013). Jak młodzi rozumieja patriotyzm? Rozmowa z socjologiem, http://www.dziennikbaltycki.pl/artykul/883496,jak-mlodzi-rozumieja-patriotyzm-rozmowa-z-socjologiem,id,t. html? cookie=1, dostęp: 30.04.2015.

Wojnicka K., Ciaputa E. (2011). Wprowadzenie: refleksja naukowa nad społeczno-kulturowymi fenomenami męskości. [W:] K. Wojnicka, E. Ciaputa (red.). Karuzela z mężczyznami. Problematyka męskości w polskich badaniach społecznych. Kraków, s. 12-13.

Wołyniec E. (2014). Zlajkowany czy zhejtowany - zalogowany w kulturze. Analiza portretu wspótczesnego nastolatka - stan i zagrożenia. [W:] J. Nikitorowicz, J. Muszyńska, B. Boćwińska-Kiluk (red.). Od wielokulturowości miejsca do międzykulturowości relacji społecznych. Współczesne strategie kreowania przestrzeni życia jednostki. Warszawa, s. 90.

Wood S.E., Green-Wood E.R. (1999). The World of Psychology. Needham.

Wygrało „Oblicze” Szymona Kołody!!!, http://ogladamczujemysle.blogspot.com/, dostęp: 20.04.2015.

Zamojska E. (1998). Kulturowa tożsamość młodzieży. Studium empiryczne. Z badań nad młodzieża ze szkót średnich. Toruń. 
